\title{
New coordinates of accounting academic education. A Romanian insight
}

\author{
Victoria Stanciu ${ }^{\mathrm{a}, 1}$, Irina Bogdana Pugna ${ }^{\mathrm{a}}$ and Mirela Gheorghe ${ }^{\mathrm{a}}$ \\ ${ }^{a}$ Bucharest University of Economic Studies, Romania
}

\begin{abstract}
Research question: Are accounting graduates prepared to face IT developments in their profession? Motivation: The accounting profession is facing a rapid transformation involving digital technology that implies significant changes. "Modern accountants are expected to have a high level of IT knowledge and skills and towards that direction the curriculum in accounting education have to adopt a wide range of modules in order to provide accounting students with the required competencies" (El-Damarleh, 2017: 202). Today's students are digital natives and they "think and process information fundamentally differently from their predecessors" (Prensky, 2001: 1). Academic education needs to adapt to the language of digital natives and provide them with new skills and the knowledge required by the profession. Idea: We aim to investigate the awareness of bachelor students in accounting regarding the impact of IT on accounting processes and their preparedness in this regard. Tools: Data was collected using a multiple-choice questionnaire distributed to third-year and master's accounting students at the Bucharest University of Economic Studies. Data was analyzed using Excel. Findings: The students are aware of the importance of the new technologies and applications relevant to the profession, but their knowledge needs to be improved. The current curriculum does not include important aspects of the new digital technology that are already embedded or being assimilated within the accounting profession. Contribution: The paper provides recommendations regarding accounting academic education, providing arguments for developing IT-related competencies for accounting students aiming to align their knowledge and skills to current and future professional requirements. The conclusions emphasize the need
\end{abstract}

\footnotetext{
${ }^{1}$ Corresponding author: Prof. Victoria Stanciu, Department of Management Information Systems, The Bucharest University of Economic Studies; 6 Piata Romana, Bucharest; tel. (+40) 0213191901; email addresses:victoria.stanciu@ cig.ase.ro
} 
of a new approach in the accounting teaching and understanding of the accounting flows and processes in a high IT environment.

Keywords: accounting graduates, future of accounting profession, digital accounting, IT knowledge and skills.

\section{JEL Codes: A2, I25, M41}

\section{Introduction}

All companies face a digital transformation that impacts their business models and, as a result, their areas of operation. At the same time, this digital transformation is visible throughout the entire value-added chain. Accounting is facing the same dynamic change. There is a huge potential for accounting to develop through digitalization and this has several components: accounting new approach and understanding; cost reduction; and a strongly IT-oriented job profile for professional accountants. The digitalization of accounting processes is present in all companies at different stages: robots have already replaced "classical" accounting data-input jobs; accounting processes are optimized; data processing is integrated; and data quality and consistency is ensured. Moreover, the work of auditors in a digital environment becomes more efficient, effective and proves increased quality.

Accounting continues to remain the "business language". As business has changed dramatically, as a result of IT, accounting has had to adapt rapidly to new business requirements. Of course, accounting principles remain the same, but accountants are nevertheless leveraging the knowledge and huge advantages offered by information technology. Mobile devices (including smartphones), social media, and Apps are part of this move to digitalization, which also includes cloud computing, eXtensible Business Reporting Language (XBRL), Big data and data analytics, and artificial intelligence, along with IoT developments. "Real-time reporting, cloud computing and complex big data analyses do not, as yet, play a large role for most companies" (KPMG, 2017: 6). The pressures of business competition impose rapid changes in companies' decision-making processes that will propel IT developments in the accounting landscape, as accounting provides the needed information.

In this increasingly IT-based environment, for (re)defining the accounting function it is important to investigate the professional technical skills needed by accountants. This study investigates the developmental trends of digitalization in accounting and the new professional profile of accountants. In this regard, we address the main issues relating to the technology skills, as our aim is to investigate the impact of disruptive technologies on accounting education. The foundation of the accounting professional is ensured through academic education. We discuss the need for a new approach in the accounting academic education starting from the new profile of the 
accounting student. "Our students today are all "native speakers" of the digital language of computers" (Prensky, 2001) and the entire training process has to be rethought from this perspective. It is also important to emphasize the other side of the coin: the academic staff is, largely, formed by so called "digital immigrants". In this context, it is not only the academic curricula to be reviewed, but also the academic training process itself. Is the academic staff properly prepared to teach digital natives? Has the academic staff the instruments required to align academic education with their students' needs, styles and ways of thinking? These questions provide a broad field for discussion and need urgent responses, followed by appropriate changes to academic education.

The objective of this paper is to assess final-year accounting students' awareness and coverage of the new technology skills required by the profession. We aim to respond to the following research question: Are accounting graduates prepared to face IT developments in their profession?

Our research reveals significant gasps in the academic training of Romanian accounting students regarding the new IT requirements of the profession. As Romanian universities are integrated in the European academic structures and programs it is important the permanently update of the curriculum and alignment to the European academic training values and trends, to the dynamic of profession and job market requirements. The most significant findings of this study include the main IT areas with an important impact on the accounting and audit professions that are not covered by the curricula, the students' expectations in terms of information technologies that should be covered in their courses, and the students' perception related to the IT-based training.

The reminder of this paper is divided into 4 sections. We begin with a review of both the scientific and business literature covering subjects relating to our research: new technologies impacting accounting profession; new skills for accounting; and an overview of reactions in accounting education. The main sections of the paper cover our research methodology and the results of our research. The last section includes some conclusions, comments on the limitations of the current study, and directions for further investigation.

\section{Literature review}

We structure our review of the literature in three subsections. In the first two we provide a survey of the relevant background and the context of our investigation. This cover, in turn, the areas of the main new technologies that impact accounting and the new skills required for accounting professionals. Our final subsection covers research most directly linked to our investigation: the way accounting education addresses new technologies impacting the profession. 


\subsection{The current technological landscape}

The business landscape is constantly challenged by technological innovation. New information technologies have reshaped existing business models and encourage the emergence of new ones. These changes impact all industries and business areas and require new sets of skills for both the present and the next generation of managers and professional employees. As noted in a survey undertaken by the American Institute of CPAs and the Chartered Professional Accountants of Canada, "technology is a crucial key to success, in the accounting profession and elsewhere" (CPA Survey, 2015: 4).

The main technologies impacting accounting and audit areas are:

\section{Analytics}

Analytics are data driven processes that creates insight. They are quantitative rather than qualitative techniques and are largely based on data and less on opinion. The Institute for Operations Research and Management Science (INFORMS) proposes three levels of analytics: descriptive, predictive and prescriptive.

Descriptive analytics refers to understanding the past (what has happened) and knowing what is happening in the organization. They are largely based on multidimensional analyses of historical data. Data warehousing, OLAP and Data Visualisation are key technologies in this area. Descriptive analytics are critical for monitoring the organization's performance. Therefore, their most common applications are in the areas of business reporting and performance management Business Performance Management Systems, dashboards, and scorecards. This category is generally identified with Business Intelligence (BI).

Predictive analytics are used to predict events (what will happen), explain when and why (why will it happen) they might occur. This type of analysis is based on statistical techniques and on Mining technologies (Data Mining, Text Mining, Web Mining).

Going forward, there is a shift towards prescriptive analytics - using simulation, optimization, decision modelling and rules to prescribe the most effective path to maximise opportunities (what should we do).

In the context of computerized decision support, Business Analytics (BA) increasingly replaces the term Business Intelligence (BI). Many academics and practitioners consider $\mathrm{BI}$, addressing mostly descriptive analytics, as being only a component of BA, together with advanced analytics, information management, change management, business strategy, and organizational design. 


\section{Big Data}

The concept of Big Data (BD) refers to sources, variety, velocity and volumes of data. The term itself is a misnomer, as it includes, beside volume, other important dimensions (Turban, 2018):

- Variety - refers to data types and data sources. Big Data includes everything - from structured (traditional databases, historical data stores) to semistructured and unstructured data (text documents, e-mail, audio and video data, sensor-captured data, and stock ticker data).

- Velocity - refers to the speed at which data is produced and the necessary speed of processing it to meet a particular need.

- Veracity - refers to the data conformity to facts (accuracy, quality, truthfulness).

- Variability - refers to the consistency of data generation in time.

- Value - Big Data has a greater potential to contain more valuable information (patterns, outliers) than small data.

BD by itself has only a hypothetical value. Business users have to explore and analyze it in order to access its potentially valuable insight. This is done with advanced analytics in a systematic approach (Business Analytics). BD analytics include Hadoop, Map Reduce and NoSQL.

BD and BD Analytics are changing the way companies use sophisticated information technologies to gain insight from data in order to support effective decision making. The availability of all this data means that "virtually every business or organizational activity can be viewed as a BD problem or initiative" (Davenport, 2014: ix). BD and its analytics initially disrupted customer-facing industries, as the levels of both variety and velocity of customer data are extremely high. Even if accounting and audit use mostly structured data, the value of BD can't be ignored in these fields. Business reporting, performance management, risk management, and regulatory compliance are only some of the areas that can be addressed using BD Analytics.

\section{Artificial Intelligence}

Artificial Intelligence (AI), the philosophy of creating intelligent machines, has become a prominent business slogan. In its brief history, AI experienced both periods of enthusiasm and of disappointment (so-called "AI winters"). Without doubt, AI is flourishing today, and its technologies are considered to be "critical in bringing about innovation, providing new business models, and reshaping the way businesses operate" (Akerar, 2019: 5). 
AI encompasses many areas, each with different approaches and technologies. Currently, the most influential for accounting and auditing are:

- Machine Learning (ML) - involving the development of computational approaches to make automatic sense of data. A machine can learn from its own experience and become "smarter" over time. Learning algorithms and ML technologies are used in Data Mining and advanced analytics to extract valuable insight from huge quantities of data.

- Knowledge based systems. Designed in a cognitive approach, they represent one of the most successful practical areas of AI. Knowledge Representation and Artificial Reasoning are the main pillars of knowledge-based systems. Rule-based knowledge bases, heuristic reasoning, uncertainty, capacity to justify a solution and to explain the logic of applying knowledge in a particular context, are all features of pragmatic systems that are capable of storing human expertise and using it to solve difficult and complex problems. These systems (called Expert Systems) are largely used as Automated Decision Systems. Accounting is one area that can be, at least partially, automated. As accounting software programs are becoming more automated, the role of the accountant is changing to that of a business advisor (Roger CPA Review, 2018).

- Natural Language Processing - used for information retrieval in the process of text mining. This can be extremely useful for auditing - using advanced machine learning techniques, auditors can rapidly process, highlight, and extract, key information from electronic documents (ICAEW, 2019). With the repetitive and low judgment areas of information extraction being automated, auditors can focus their effort on more important cognitive aspects.

\section{Blockchain}

Blockchain is a transformative and relatively early-stage information technology, with a significant disruptive potential. Some consider it as a broad ecosystem of digital automation opportunities, expecting it to be as revolutionary as the Internet (Dai \& Vasarhelyi, 2017: 5).

Originally developed as a method for documenting cryptocurrency transactions, blockchain's functionality has evolved into a large number of applications - such as banking, financial markets and insurance. Many organizations are currently recognizing the potential of blockchain technology, and some of them are investing in this area. Its application to accounting and auditing practices is still underexplored. However, its potential to enable a real-time, verifiable, and transparent accounting ecosystem is largely acknowledged both by researchers and practitioners.

Some have suggested "the future possibility of triple entry accounting where every accounting transaction recorded by an entity also has a corresponding posting onto 
a public blockchain" (Carlin, 2018: 12). The concepts of smart contracts and tripleentry accounting can have an important impact on audit. As all transactions are verified by an independent source and a complete history of all transactions available on the blockchain, the audit focus will move to the terms of the smart contract itself. Auditing can then change from being an annual event (looking back at "historical data") to a real-time process - and this will have an important effect on corporate reporting.

"Blockchain could enable a real-time, verifiable, and transparent accounting ecosystem. Additionally, blockchain has the potential to transform current auditing practices, resulting in a more precise and timely automatic assurance system" (Dai \& Vasarhelyi, 2017: 5).

\subsection{New technology skills for accounting}

The new business model is predominantly data-driven, with (big) data analytics being one of the main processes for management and value creation. Therefore, organizations are struggling to become data-driven and to increase their IQ by strategically using the valuable insights provided by advanced analytics. Business leaders are searching for cognitive, soft, and technological high-level skills in their effort to create competitive advantages from the opportunities offered by technology. According to one of the latest surveys that investigated 60 banks, insurance and asset management firms, $48.5 \%$ of the executives identify people challenges as the greatest barrier to become data-driven, while the technology issue was cited only by $19.1 \%$ (Bean, 2018).

These new technologies will rapidly and significantly affect the workplace. An estimate is that at least $50 \%$ of the work is automatable through currently available technology, and an additional 15\% is automatable through forthcoming technologies (Manyka et al., 2017). New workplaces, with high levels of automation, AI, and with deep analytical insights, will need employees with novel knowledge and skills, eager to learn continuously and to treat change as a constant in their professional life.

Both the accounting and audit professions are challenged by all these trends. To succeed in the current global market, skills like problem-solving, critical thinking, continuous learning and ability to engage with new technological developments are required (McKinney et al., 2017). Employers ask for generic skills (personal and soft skills), accounting-specific skills (such as accounting principles, accounting standards) and technology skills. The last are changing dynamically, and businesses expect their talent to adapt to these changes.

The Big Four are searching for people having, besides accounting and auditing knowledge, analytical skills and computer programming experience (Cooper et al., 
2018). Ernst \& Young defined the "accounting plus" skills framework, including knowledge of techniques such as: analytic modelling; data visualization; intelligent process automation; Watson and deep learning methodology; blockchain and smart contracts; and cybersecurity (Ernst \& Young, 2018). PwC recognize skills in data analytics, information management, and programming languages as more valuable than ever (PwC, 2015). The Association of Accountants and Financial professionals in business (IMA) includes in its Management Accounting Competency Framework skills like: the ability to analyze data using business intelligence software; use data analytics and data mining techniques to discover key and relevant trends; and synthetize and interpret data from multiple sources (IMA, 2017). Some other large and midsized firms have expressed similar views. Analytical capabilities and the ability to work with data analytics are the main skills required by the employers.

Based on this literature review and on the authors own experiences, the technical skills needed by the accountants are synthetized in the Table 1.

Table 1. Technical skills recommended to the accountants

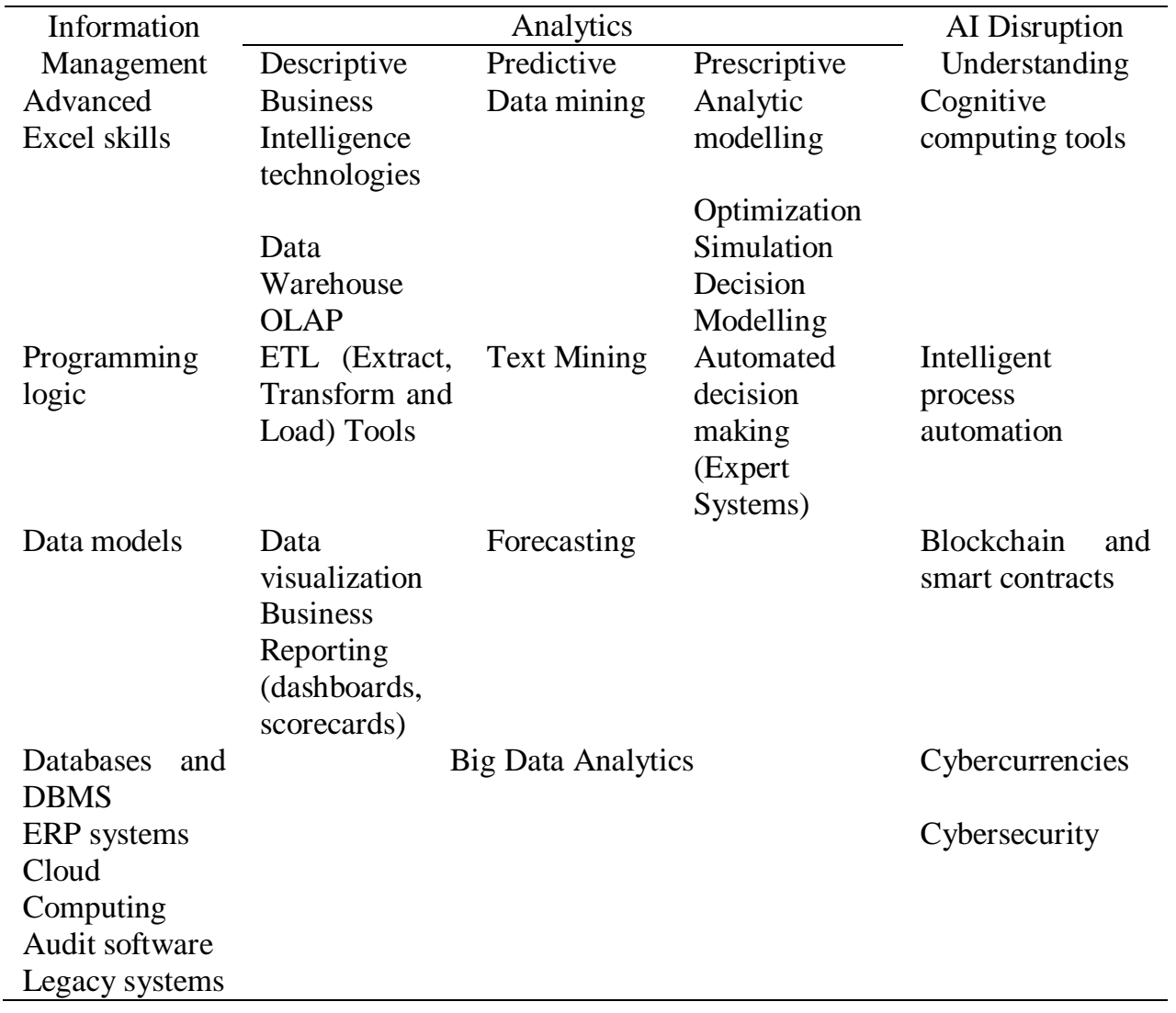

Vol. 19, No. 1 
It is reasonable to conclude that the accounting profession will need people having accounting skills but who are also extremely literate. Also, the need for soft skills professional skepticism, judgment, and critical thinking - will remain a constant for accounting and audit professionals.

\subsection{The impact of disruptive technologies on accounting education}

Technology disruption is already happening, and education providers should prepare current and future generations accordingly. The lack of skills - both technology and technology-related - is one of the most important constraints acknowledged by business leaders in their effort to respond to the challenges raised by the ongoing technological revolution. According to Davenport, these changes in skills and analytical orientations may require "a generational change in company leadership" (Davenport, 2017). The idea that analytics should be a distinct business discipline and that universities should prepare students to become "citizens of data science" (Schwarzo, 2018) is itself a measure of this need for people with appropriate skills and attitudes in the contemporary business landscape.

Accounting, "a profession that is stepped in tradition and surrounded by frameworks and concern for regulatory challenge, it is going to take a concerted effort to embrace and proactively respond to the opportunities and challenges that the digital and technological revolution will bring" (Zhang et al., 2018: 4). The profession needs to embrace these changes in order to remain relevant. Today's accounting curriculum should be updated to equip students with new skills, especially in technology and data analytics.

Accounting curricula and education in most countries have not substantially changed (Zhang et al., 2018). However, there are some universities that are trying to introduce new courses and new interdisciplinary programs to fill the gap. Some examples are:

- Queen Mary University (UK), whose undergraduate program includes courses on how to discover patterns in finance and accounting domains.

- The University of Waterloo (Canada) integrates a basic curriculum of analytics within its undergraduate and graduate programs.

- The Southern University of Finance and Economics in Chendu, China offers an undergraduate program for business analytics in accounting, including disciplines like databases, data mining, data analytics and machine learning together with disciplines of core accounting knowledge.

- Singapore Management University has established a master's degree in accounting data and analytics.

- The USC Marshall School of Business offers a Master of Accounting with Data and Analytics.

- St. Mary University (Texas, USA) offers a program in Accounting and Data Analytics, including courses such as accounting, data analytics, information systems management and quantitative management. 
- The University of Pittsburgh has established a master's in Accounting and Business Analytics.

There are also initiatives that integrate accounting courses in programs aiming to prepare data scientists. For example, the University of Pennsylvania, which includes a course on Accounting Analytics in its program covering Business Analytics.

Along with these innovations within higher education, major employers are increasingly involved in the accounting education process. For example, one of the Big Four auditing firms (KPMG) has established partnerships with a number of schools (9 universities in the USA in January 2018) to sponsor master's programs focused on data analytics in accounting. These programs include courses that combine accounting with big data analytics: Auditing through Information Systems, Data Analysis and Visualization, Probability, Uncertainty, and Statistical Decision Making and Data Mining for Business Intelligence.

Educators need to be aware that new technologies continue to develop, and that dynamic sociotechnical change creates volatility for accounting education (AlHtbayat et al., 2018). Therefore, it is important to keep a proper balance between innovation and stability in the development of curricula, assuming that continuous learning and the ability to engage with new developments and data are essential skills for their graduates. Educators should encourage a philosophy of lifelong learning.

The accounting context needs to be considered for future curriculum development and the accounting and audit professions need to respond proactively to the technology challenge in order to remain relevant.

\section{Methodology}

Aiming at addressing our objective, we undertook a qualitative investigation. The process of reviewing the literature emphasized the major IT challenges for the accounting profession and helped us state the main coordinates for the empirical study.

This qualitative investigation was followed by an empirical investigation, our objective being to investigate the awareness of new-entry accounting professionals on the impact of IT on accounting processes, and their preparedness in this regard. The study's target group were accounting students at the Bucharest University of Economic Studies (the last year of bachelor's degree and master students). The criteria used in establishing the target group took into consideration that [i] the students belong to Gen Y which is more receptive to new technologies; and [ii] they are new entries into the profession; their perceptions are relevant to this study, regarding IT developments in the accounting profession and their related knowledge and skills. 
Data was collected using a multiple-choice questionnaire distributed randomly to third-year bachelors and accounting master students. The questionnaire, containing 18 questions, was structured in two parts: the first part includes demographic questions aiming to gather the respondents' field, level of study, and gender. The second part includes questions focusing on students' awareness of IT developments in the profession, and their perceptions regarding their knowledge in the field. The questionnaire includes multiple-choice and rating scale questions (a Likert scale, with five degrees, was used) aiming to assess the students' in-depth knowledge and preferences regarding new information technologies impacting the accounting field. The data collection took place between December 2018 and January 2019; we collected 102 questionnaires, none of them being rejected. The collected data was analyzed using Excel, applying descriptive statistical methods to determine mean values, standard deviations, and percentages.

It is important to articulate the researcher's relationships to this study. We are all faculty members, teaching Management Information Systems courses. Therefore, we have the position of active and informed observers of the phenomenon under study. Moreover, we had an initial assumption regarding the necessary technology skills of accounting professionals - assumptions based on the scientific literature, the business literature, and our academic experiences (Table 1).

\section{Results and discussion}

We conducted the data analysis based on the following questions:

1. What are the students' perceptions regarding their academic formation for the profession?

2. What are the most important study domains for accounting students?

3. How important are IT courses for their professional accounting academic training?

4. What are the main technologies impacting the accounting profession?

5. How well prepared are they regarding these technologies?

The structure of the analyzed sample includes 102 subjects, the demographic structure being presented in Table 2. The sample corresponds to the overall gender distribution at the Bucharest University of Economic Studies.

Table 2. Demographic data

\begin{tabular}{lcc}
\hline & No. of respondents & \% \\
\hline Bachelors & 82 & $80.39 \%$ \\
Master students & 20 & $19.61 \%$ \\
Female & 82 & $80.39 \%$ \\
Male & 20 & $19.61 \%$ \\
\hline
\end{tabular}

We question what skills and competencies are considered necessary for the future accounting profession. The five domains nominated in the predefined answers were: 
accounting and audit, computing, law, financial analysis, and taxation. The respondents appreciated that knowledge and abilities in computing are essential, after accounting and auditing.

Table 3. Respondents' perception in regard with the importance of the five education domains

\begin{tabular}{cccccc}
\hline & $\begin{array}{c}\text { Very } \\
\text { important }\end{array}$ & Important & $\begin{array}{c}\text { Moderately } \\
\text { important }\end{array}$ & $\begin{array}{c}\text { Slightly } \\
\text { important }\end{array}$ & $\begin{array}{c}\text { Not } \\
\text { important }\end{array}$ \\
\hline $\begin{array}{c}\text { Accounting and } \\
\text { audit }\end{array}$ & $72 \%$ & $9 \%$ & $10 \%$ & $4 \%$ & $2 \%$ \\
$\begin{array}{c}\text { Informatics } \\
\text { Law }\end{array}$ & $33 \%$ & $31 \%$ & $15 \%$ & $10 \%$ & $6 \%$ \\
Financial & $13 \%$ & $20 \%$ & $21 \%$ & $22 \%$ & $20 \%$ \\
$\begin{array}{c}\text { accounting } \\
\text { analysis }\end{array}$ & $25 \%$ & $24 \%$ & $25 \%$ & $16 \%$ & $4 \%$ \\
Taxation & $31 \%$ & $30 \%$ & $15 \%$ & $14 \%$ & $2 \%$ \\
\hline
\end{tabular}

The responses reflect the students' awareness of the deep integration of the automated processes in the accounting flows and is the result of their academic training focused on management information systems and other computing topics. The accounting knowledge and competences are in first place, which is compulsory for the accounting students; the percentage of 72 could be subject of discussion. Computing skills are in second place: just $64 \%$ of the respondents considering these competences important and very important for the profession (Table 3). In our opinion, students are not benefiting from integrated accounting and computing lessons that raise potential gaps in their understanding of the accounting processes in the automated flow.

We also investigated the respondents' perceptions regarding the importance of the computing lectures for their training. $72 \%$ of respondents considered that the computing classes are important and very important for their training which confirms the responses received for the first question (Figure 1).

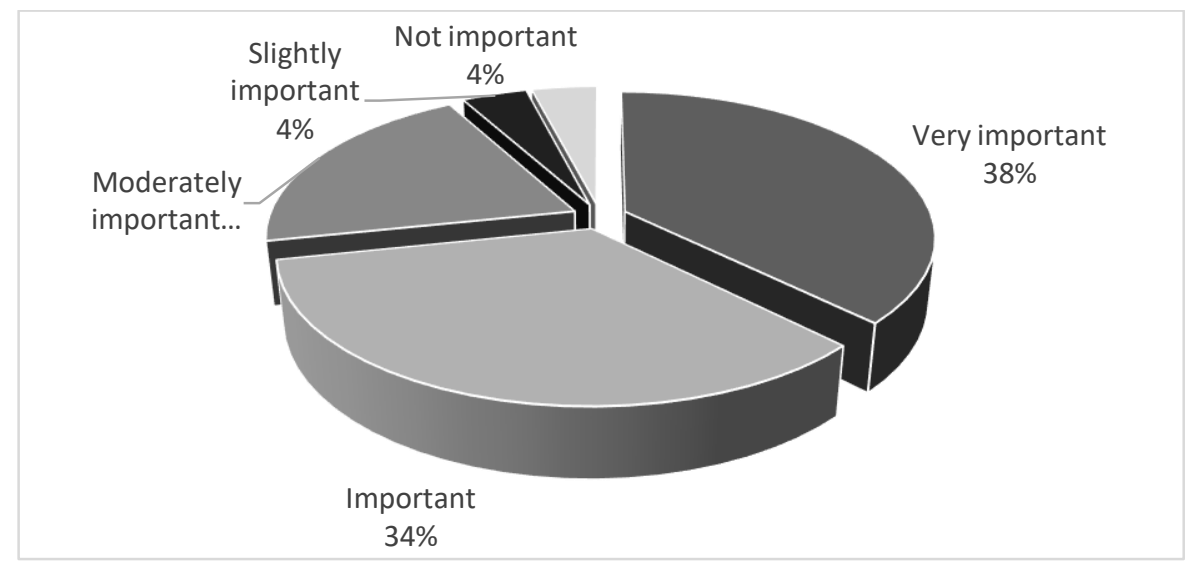

Figure 1. Respondents' perception regarding the importance of the computing 
Another topic we explored was the students' perceptions regarding the computing courses included in the bachelor curriculum. The predefined answers in the survey's question were (according with the curriculum): Office Automation Systems (OAS), (SGBD) Access, Programming, WEB Design, Management Information Systems (MIS), Business Intelligence (BI), and SQL Server. From the results of data analysis, we retain students' focus on OAS and Access (Table 4). As Excel is one of the most important tools included in the curriculum, and still the most important tool used by accountants and auditors, the answer is well aligned with the actual state of the Romanian accounting and auditing profession. We expected that awareness of the importance of database management systems and management information systems would be more strongly emphasized. The answers should be considered noting that most of the students are not working in the field and they are not familiar with the tasks and activities performed in the accounting departments. As $80 \%$ of the respondents are in the $3^{\text {rd }}$ year, and they have yet to participate in the BI classes, their answers reflect their limited knowledge on BI topics from other sources.

Table 4. Students' perception in regard with the importance of the computing classes included in the bachelor curriculum

\begin{tabular}{cccccc}
\hline & $\begin{array}{c}\text { Very } \\
\text { important }\end{array}$ & Important & $\begin{array}{c}\text { Moderately } \\
\text { important }\end{array}$ & $\begin{array}{c}\text { Slightly } \\
\text { important }\end{array}$ & $\begin{array}{c}\text { Not } \\
\text { important }\end{array}$ \\
\hline OAS & $75 \%$ & $14 \%$ & $6 \%$ & $0 \%$ & $5 \%$ \\
ACCESS & $18 \%$ & $34 \%$ & $27 \%$ & $13 \%$ & $6 \%$ \\
Programming & $10 \%$ & $19 \%$ & $23 \%$ & $26 \%$ & $22 \%$ \\
WEB Design & $13 \%$ & $15 \%$ & $26 \%$ & $24 \%$ & $20 \%$ \\
MIS & $19 \%$ & $25 \%$ & $25 \%$ & $21 \%$ & $9 \%$ \\
Business & $13 \%$ & $11 \%$ & $23 \%$ & $22 \%$ & $16 \%$ \\
Intelligence & $14 \%$ & $23 \%$ & $30 \%$ & $19 \%$ & $11 \%$ \\
SQL Server & $14 \%$ & & &
\end{tabular}

Table 5. Statistic data descriptive analysis for computing classes included in the bachelor curriculum

\begin{tabular}{ccccc}
\hline & Mean & $\begin{array}{c}\text { Standard } \\
\text { Error }\end{array}$ & $\begin{array}{c}\text { Sample } \\
\text { Variance }\end{array}$ & $\begin{array}{c}\text { Standard } \\
\text { Deviation }\end{array}$ \\
\hline OAS & 4.5 & 0.11 & 1.16 & 1.08 \\
ACCESS & 3.39 & 0.12 & 1.45 & 1.20 \\
Programming & 2.66 & 0.13 & 1.69 & 1.30 \\
language & & & & \\
WEB Design & 2.69 & 0.13 & 1.86 & 1.36 \\
MIS & 3.15 & 0.13 & 1.81 & 1.34 \\
Business & 2.33 & 0.16 & 2.54 & 1.59 \\
Intelligence & & & & \\
SQL Server & 2.90 & 0.13 & 1.76 & 1.32 \\
\hline
\end{tabular}

The sample variance reflects the responses exceeding the mean value of the responses; it can be retaining the homogeneity of the answers (Table 5). The master 
students appreciate that OAS are very important and important for their profession $(90 \%)$ and the data base classes are rather moderately important, being known that all the accounting systems are based on such data structures. This emphasizes their user accounting software approach and their limited understanding of the accounting processes in the dedicated accounting systems. This can be explained by their new entering jobs in the profession, having, in most cases, data entering attributions in the accounting applications that determine a user approach in regard with the automated accounting processing.

In order to see if there are major differences between the bachelor's and the master student's answers we applied the statistic test $\mathrm{T}$. The results are presented summarily in table 6 and based on their analysis it can be easily observed that there are no significant differences between the assessments made to the disciplines OAS, ACCESS, Programming language, BI and SQL Server (by verifying criteria t Stat < t Critical, $p>0.05$ ). On the other hand, it can be observed that for the disciplines WEB Design and MIS, the assessments made by the bachelors are distinct than the master students, in the sense that the bachelors attach greater importance to them.

Table 6. Statistic t-Test: Two-Sample Assuming Unequal Variances for bachelors versus master students

\begin{tabular}{cccccc}
\hline & t Stat & $\begin{array}{c}\mathbf{P}(\mathbf{T}<=t) \\
\text { one-tail }\end{array}$ & $\begin{array}{c}\text { t Critical } \\
\text { one-tail }\end{array}$ & $\begin{array}{c}\mathbf{P}(\mathbf{T}<=\mathbf{t}) \\
\text { two-tail }\end{array}$ & $\begin{array}{c}\text { t Critical } \\
\text { two-tail }\end{array}$ \\
\hline OAS & -0.94 & 0.17 & 1.67 & 0.34 & 2.00 \\
ACCESS & 1.575 & 0.06 & 1.701 & 0.126 & 2.048 \\
$\begin{array}{c}\text { Programming } \\
\text { language }\end{array}$ & 1.171 & 0.125 & 1.699 & 0.250 & 2.045 \\
WEB Design & 2.852 & 0.003 & 1.697 & 0.007 & 2.042 \\
$\quad$ MIS & 2.509 & 0.008 & 1.697 & 0.017 & 2.042 \\
$\begin{array}{c}\text { Business } \\
\text { Intelligence }\end{array}$ & -0.255 & 0.399 & 1.683 & 0.799 & 2.021 \\
SQL Server & 1.069 & 0.146 & 1.699 & 0.293 & 2.045 \\
\hline
\end{tabular}

The next two questions investigated the new technologies impacting the accounting profession. The predefined answers were: Business Intelligence, Big Data, Cloud Computing, IoT, Blockchain, Artificial Intelligence, Applications for data security, and Apps for mobile devices. Analyzing the responses, we note that the students are aware of the importance of the new technologies (Figure 2) and Apps but their knowledge of these topics is rather low (Figure 3). As the courses included in the current curriculum do not cover all the investigated technologies/applications, these results are in line with the reality. This should trigger a review of the curriculum not just in its content but also in the number of training hours allocated for the specific courses. 


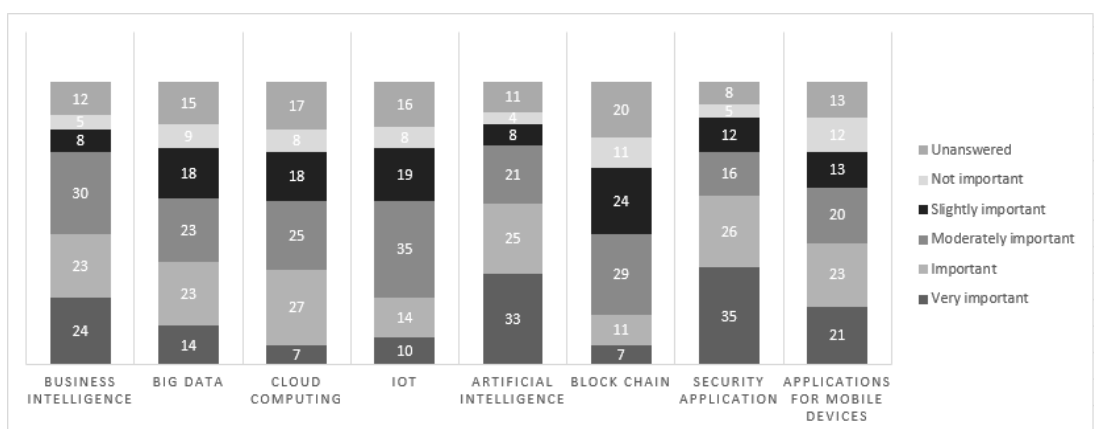

Figure 2. Which are the technologies/tools impacting the profession?

Table 7. Statistic data descriptive analysis for technologies/tools impacting the profession

\begin{tabular}{ccccc}
\hline & Mean & Median & $\begin{array}{c}\text { Sample } \\
\text { Variance }\end{array}$ & $\begin{array}{c}\text { Standard } \\
\text { Deviation }\end{array}$ \\
\hline Business Intelligence & 3.16 & 3 & 2.49 & 1.58 \\
Big Data & 2.70 & 3 & 2.56 & 1.60 \\
Cloud Computing & 2.56 & 3 & 2.36 & 1.54 \\
IoT & 2.52 & 3 & 2.23 & 1.49 \\
Artificial Intelligence & 3.41 & 4 & 2.60 & 1.61 \\
Blockchain & 2.20 & 2 & 2.20 & 1.48 \\
Security Application & 3.49 & 4 & 2.43 & 1.56 \\
Application for mobile devices & 2.89 & 3 & 2.81 & 1.67 \\
\hline
\end{tabular}

The standard deviation indicates small variances in the respondents' perceptions, meaning that they seem to have similar views regarding the impact of IT developments on the profession (Table 7). Taking into consideration that the previous responses reflected the students' awareness of the IT impact on the profession, the mean and median values calculated for the present responses reflect that students are not familiar with the indicated IT developments. We asked the students which computing topics need to be included in the IT classes. The respondents expressed their interest in accounting Apps, AI, cloud computing, blockchain, programming (Java), IoT for E-Business, and cybersecurity, recognizing their insufficient knowledge on these topics. 


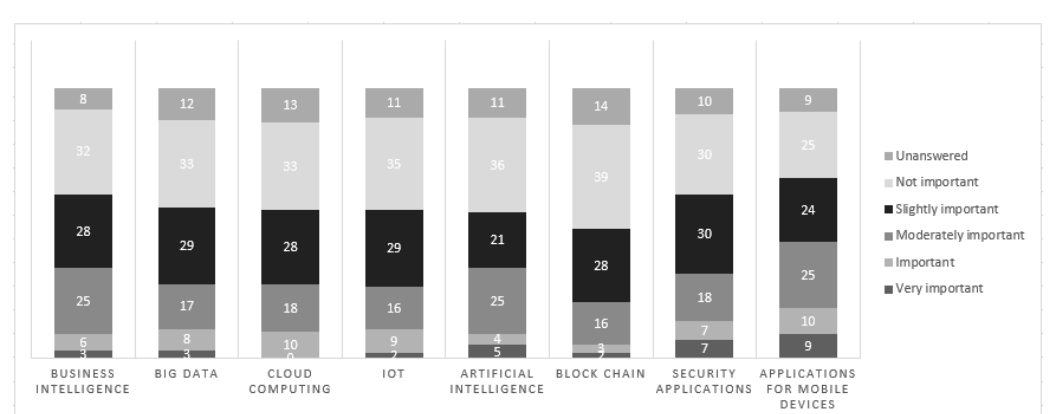

Figure 3. How do you rate the level of knowledge you acquired on the technologies and applications mentioned

We investigated the students' perception regarding the factors influencing IT adoption in accounting departments. The predefined answers were: increase the work efficiency, service quality, complex analysis of financial accounting data, availability of 24/24 services online, integrity and security of financial accounting data. The responses are provided in table 8 and emphasize the students' focus on the quality of the services and on increasing work efficiency (Table no. 8 contains the number of answers for each option).

Table 8. Factors influencing IT\&C adoption

\begin{tabular}{cccccc}
\hline & $\begin{array}{c}\text { Very } \\
\text { important }\end{array}$ & Important & $\begin{array}{c}\text { Moderately } \\
\text { important }\end{array}$ & $\begin{array}{c}\text { Slightly } \\
\text { important }\end{array}$ & $\begin{array}{c}\text { Not } \\
\text { important }\end{array}$ \\
\hline Efficiency of & 69 & 18 & 8 & 2 & 4 \\
work & 96 & 2 & 3 & 0 & 1 \\
$\begin{array}{c}\text { Service quality } \\
\text { Complex analysis } \\
\text { Availability of } \\
24 / 24\end{array}$ & 41 & 28 & 21 & 6 & 4 \\
$\begin{array}{c}\text { Integrity and } \\
\text { security }\end{array}$ & 39 & 29 & 18 & 8 & 7 \\
\hline
\end{tabular}

We asked the students' for their opinion regarding the use of dedicated accounting applications rather than paper-based work in their training. Students appreciate that using accounting applications is beneficial: $46 \%$ consider very important for their training and 33\% as important (Figure 4). 


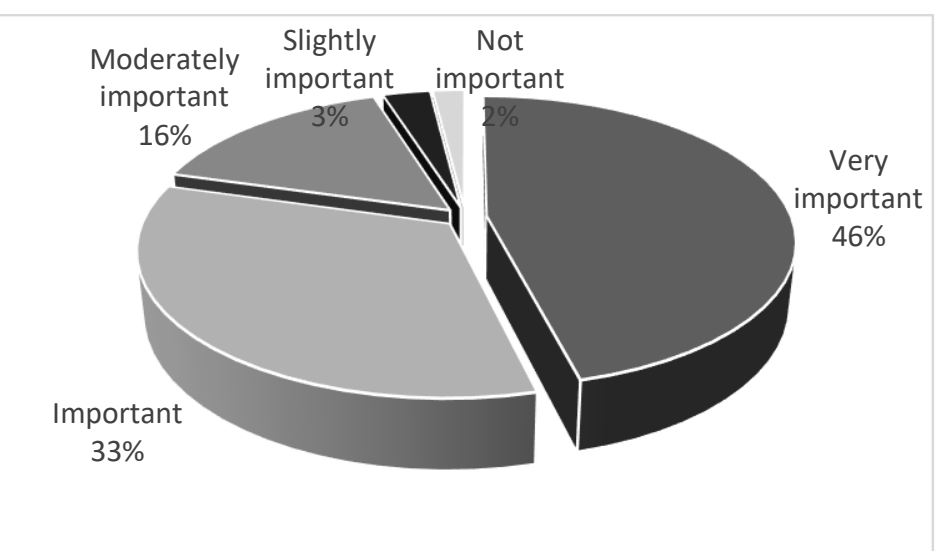

Figure 4. Accounting knowledge is better acquired using accounting applications?

The respondents appreciate the usefulness of computer skills and knowledge acquired in the academic training for their professional accounting work. $40 \%$ totally agree that they will use the IT skills and knowledge, and 26\% agree (figure 5). It is surprising to see that, in an IT-based environment that characterizes accounting activities, $2 \%$ of the respondents strongly disagree with the use of acquired IT skills and $7 \%$ expressed their disagreement. It could be concluded that they do not consider IT acquired skills and knowledge important for their future work or they do not need such skills for the accounting work - however, in the absence of written comment from these respondents we cannot draw a definitive conclusion. Neither of these possible explanations is in line with reality nor with the professional accounting profile.

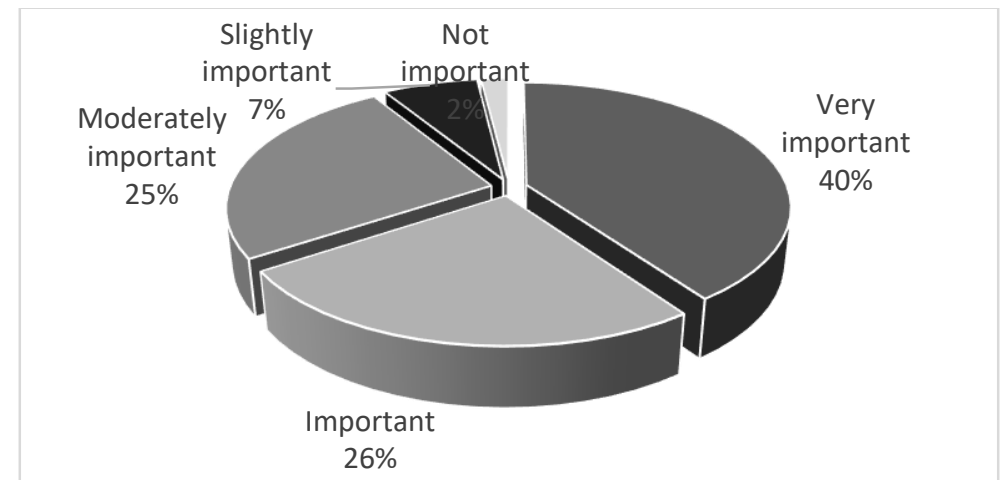

Figure 5. Will I use the knowledge of computer science disciplines in my profession?

It was also surprising to find that students are not requesting more IT-based training in the educational processes. Such training should be included throughout the curriculum, not only in the computing classes. 
If we analyze the answers based on the gender criteria, we found out that the female students are more convince than their male students on the usefulness of their computing knowledge in the profession (Table 9).

Table 9. How important is the knowledge accumulated in the computer science disciplines for your profession?

\begin{tabular}{lrrrrr}
\hline & $\begin{array}{c}\text { Very } \\
\text { important }\end{array}$ & Important & $\begin{array}{c}\text { Moderately } \\
\text { important }\end{array}$ & $\begin{array}{c}\text { Slightly } \\
\text { important }\end{array}$ & \multicolumn{1}{c}{$\begin{array}{c}\text { Not } \\
\text { important }\end{array}$} \\
\hline Female & $42.68 \%$ & $25.61 \%$ & $24.39 \%$ & $4.88 \%$ & $2.44 \%$ \\
Male & $30 \%$ & $25 \%$ & $30 \%$ & $15 \%$ & $0 \%$ \\
\hline
\end{tabular}

The respondents' answers reflect clearly that the academic curriculum should be revised to reflect the technology changes in the accounting profession. The dynamic in the IT area and the rapid adoption in the accounting field of the new information technologies impose not just their presentation from the technology point of view but a new approach in the presentation of the accounting flow and processes, new means in performing audit tests and assessments.

\section{Conclusions}

Innovations in IT have impacted on the role of the accounting professional. In the past this role focused on financial information analysis. Increasingly, the accounting professional is becoming a consultant in the decision-making process. The study of new IT technologies is now vital for the future accountant and, consequently, all education institutions should take account of this in developing their curricula.

This paper has investigated accounting students' awareness and coverage of the new technology skills required in the accounting profession. Our study revealed significant gaps in the academic training of Romanian accounting students regarding the new IT requirements of the profession. As the students need to be educated for the labor market, both the academic curricula and the education process should be adjusted accordingly. A review of the academic curriculum needs a forward-looking strategic approach, based on at least two significant issues: the dynamics of digitalization in the accounting profession and the characteristics of the next generations of students. The university should already be preparing to train students from Generation $\mathrm{Z}$ (who are characterized as being culture creators and gadgetoriented) for their accounting professional lives. This implies new pedagogical approaches, advanced infrastructure to support the education processes, and updated curricula. Teachers should adapt their rationale and their approaches in accordance with the IT implications for accountancy and the next generation of students' ways of thinking and focus. 
In the short term, updating the syllabus of existing courses is needed in order to include the new technologies discussed in this paper. A significant shift in accounting teaching, as well as in other courses (like financial analysis and taxation), should be undertaken by embedding IT-based applications and teaching techniques. All these changes and updates should be articulated to the other EU academic curricula as long as Romanian universities are part of EU academic programs and international academic organizations.

The main limitations of this research derive from the structure of our respondents we interviewed students at the end of the first semester of their terminal year, so before the Business Intelligence course addressing the analytics topic, which is scheduled in the second semester.

Another limitation relates to the coverage of our study - we have focused only on technology skills. The professional profile of the modern accountant also requires soft skills in order to manage current IT developments and, therefore, a broader approach regarding the necessary changes in the educational process.

As a future research objective, the authors envisage a more comprehensive analysis, including students, graduates, employers, professional accounting bodies and faculty members in order to design a strategy for accounting education and initiate an academic debate regarding Romanian accounting academic education.

\section{Acknowledgements}

The paper was presented in the 14th International Conference Accounting and Management Information Systems AMIS 2019, Bucharest, Romania and the authors benefited of the debates and recommendations of the participants. The present paper integrates the recommendations and feed backs of the specialists participating to the conference.

\section{References}

Akerkar, R. (2019) "Artificial Intelligence for Business", Springer Briefs in Business, available on line at https://doi.org/10.1007/978-3-319-97436-1, January 2019.

Al-Htbayat, K., Alberti -Alhtaybat, L. \& Alhatabat, Z. (2018) "Educating digital natives for the future: accounting educators' evaluation of the accounting curriculum", Accounting Education Journal, vol. 27, no. 4: 333-357

Bean, R. (2018) "How Big Data and AI are Driving Business Innovation in 2018", MIT Sloan Management Review, Jan., available online: https://sloanreview.mit.edu/article/how-big-data-and-ai-are-drivingbusiness-innovation-in-2018/, January 2018. 
Carlin, T. (2018) "Blockchain and the journey beyond double entry", Australian Accounting Review, vol. 29: 305-311

Cooper, L.A., Holderness, D.K., Sorenson, T. \& Wood D.A., (2018) "Robotic public automation in public accounting", CPA Journal, available online at https://www.cpajournal.com/CPA

CPA Survey (2015) 25th Anniversary Edition of the North America Top Technology Initiatives Survey Results, available online at https://www.cpacanada.ca, January 2019.

Dai, J. \& Vasarhelyi, M. A. (2017) "Toward blockchain-based accounting and assurance", Journal of Information Systems, vol. 31, no. 3: 5-21

Davenport, T.H., Harris, J. \& Abney, D. (2017) Competing on Analytics: The New Science of Winning, Harvard Business Review Press

Davenport, T. (2014) Forward - in the book Big Data, Mining and Analytics components of strategic decision making, CRC PRESS, Taylor \& Francis Group

Ernst \& Young (2018) The future of Audit: Preparing Students to succeed, available online at https://www.ey.com, January 2019.

KPMG (2017) Digitalization in accounting. Study of the Status Quo in German companies, available online at https://home.kpmg/content/dam/kpmg/de/pdf/ Themen/2017/digitalisation-in-accounting-en-2017-KPMG.pdf, February 2019.

ICAEW (2019) The future of Audit: Technology, available online at https://www.icaew.com/technical/audit-and-assurance/faculty/the-future-ofaudit/the-future-of-audit-technology

IMA (2017) Management accounting competency framework, available online at https://www..imanet.org\%2Fcareer-resources\%2Fmanagement-accountingcompetencies\&usg=AOvVaw32QktnwShi2iwtng1xDnFh, December 2018.

Manyka, J., Lund, S., Chui, M., Bughin, J., Woetzel, J., Batra, P., Ko, R. \& Sanghvi, S. (2017) Jobs lost, jobs gained: what the future of work will mean for jobs, skills and wage, McKinsey Global Institute, available online at https://mck.co/ 2LCunZD, February 2019

Maguire, J. (2018) "Using Data Science in the Real World: Expert Tips", available online at https://www.datamation.com/big-data/using-data-science-in-thereal-world-expert-tips.html, January 2019.

McKinney Jr, E., Yoos, C. \& Snead, K. (2017) "The need for 'sceptical' accountants in the era of big data", Journal of Accounting Education, vol. 38: 63-80

Prensky, M. (2001) "Digital natives, digital immigrants. on the horizon", $M C B$ University Press, vol. 9, no. 5, available online at https://www.marcprensky.com/writing/Prensky\%20-\%20Digital \%20Natives, \%20Digital\%20Immigrants\%20-\%20Part1.pdf, March 2019.

PwC (2015) Data driven - What students need to succeed in a rapidly changing business world, available online at https://cpb-us-w2.wpmucdn.com /sites.gsu, edu/dist/1/1670/files/2015/08/pwc-data-driven-paper-1wdb00u. pdf, 
Roger CPA Review (2018) 5 ways technology is transforming accounting, available online at https://www.rogercpareview.com/blog/5-ways-technologytransforming-accoun ting

Sharda, R., Delen, D. \& Turban, E. (2018) Business Intelligence, Analytics and Data Science - A managerial perspective, Fourth Edition, Pearson

Zhang, C., Dai, J. \& Vasarhelyi, M.A. (2018) "The impact of disruptive technologies on Accounting and Auditing Education. How should the profession adapt?", CPA Journal, available on-line at https://www.cpajournal.com/CPA Journal Content/ September 2018 issue, January 2019. 